This article was downloaded by: [Max Planck Inst \& Research Groups Consortium]

On: 25 May 2009

Access details: Access Details: [subscription number 789998259]

Publisher Psychology Press

Informa Ltd Registered in England and Wales Registered Number: 1072954 Registered office: Mortimer House, 37-41 Mortimer Street, London W1T 3JH, UK

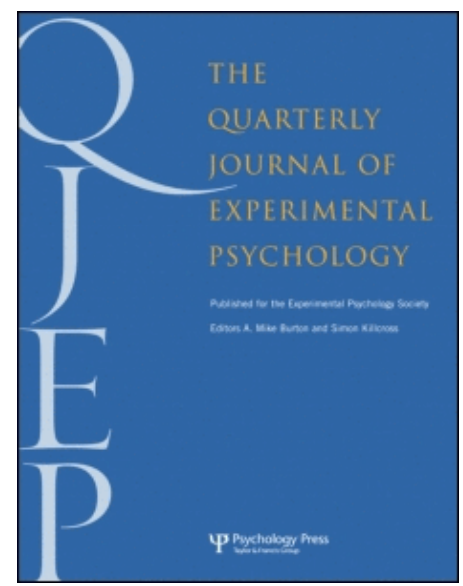

The Quarterly Journal of Experimental Psychology

Publication details, including instructions for authors and subscription information:

http://www.informaworld.com/smpp/title content=t716100704

\title{
Detection of visual patterns disturbed by noise: An exploratory study
}

\section{J. P. Van De Geer a; W. J. M. Levelt a}

${ }^{a}$ Institute for Perception, Soesterberg, The Netherlands

Online Publication Date: 01 September 1963

To cite this Article Van De Geer, J. P. and Levelt, W. J. M.(1963)'Detection of visual patterns disturbed by noise: An exploratory study', The Quarterly Journal of Experimental Psychology, 15:3,192 - 204

To link to this Article: DOI: $10.1080 / 17470216308416324$

URL: http://dx.doi.org/10.1080/17470216308416324

\section{PLEASE SCROLL DOWN FOR ARTICLE}

\footnotetext{
Full terms and conditions of use: http://www.informaworld.com/terms-and-conditions-of-access.pdf

This article may be used for research, teaching and private study purposes. Any substantial or systematic reproduction, re-distribution, re-selling, loan or sub-licensing, systematic supply or distribution in any form to anyone is expressly forbidden.

The publisher does not give any warranty express or implied or make any representation that the contents will be complete or accurate or up to date. The accuracy of any instructions, formulae and drug doses should be independently verified with primary sources. The publisher shall not be liable for any loss, actions, claims, proceedings, demand or costs or damages whatsoever or howsoever caused arising directly or indirectly in connection with or arising out of the use of this material.
} 


\title{
DETECTION OF VISUAL PATTERNS DISTURBED BY NOISE: An Exploratory Study
}

\author{
BY \\ J. P. VAN DE GEER and W. J. M. LEVELT \\ From the Institute for Perception, Soesterberg, The Netherlands
}

\begin{abstract}
An introductory study of the perception of stochastically specified events is reported. The initial problem was to determine whether the perceiver can split visual input data of this kind into random and determined components. The inability of subjects to do so with the stimulus material used (a filmlike sequence of dot patterns), led to the more general question of how subjects code this kind of visual material. To meet the difficulty of defining the subjects' responses, two experiments were designed. In both, patterns were presented as a rapid sequence of dots on a screen. The patterns were more or less disturbed by "noise," i.e. the dots did not appear exactly at their proper places. In the first experiment the response was a rating on a semantic scale, in the second an identification from among a set of alternative patterns. The results of these experiments give some insight in the coding systems adopted by the subjects. First, noise appears to be detrimental to pattern recognition, especially to patterns with little spread. Second, this shows connections with the factors obtained from analysis of the semantic ratings, e.g. easily disturbed patterns show a large drop in the semantic regularity factor, when only a little noise is added.
\end{abstract}

\section{INTRODUCTION}

In recent years several attempts have been made to construct theoretical models for aspects of the visual perception process. Some of them depend on statistical reasoning; it is assumed that it is possible for the perceiver to split input data into random and determined components, or, what amounts to the same thing, to detect the parameters which specify a stochastic process. An example of this kind of model is Rosenblatt's "Perceptron." (I958.)

Statistical separability in this sense is the subject of the experiments described in the present report. They deal with separability on the "macro" level. The consideration that they may have some bearing on separability processes in neural networks is not precluded, but this side of the matter is not our present concern. We shall investigate how far the human observer is able to keep random and determined components apart in stimulus material.

The idea behind the theory of separability is clear enough. If the input rate exceeds the channel capacity, then the organism is forced to reject data and it would be an efficient procedure to disregard random components in favour of more stable and enduring characteristics of environmental events. Even below the channel capacity perceptual load would be reduced and efficiency increased if it were possible for the organism to extract the constant components in a given mixture of determined and stochastic events. Such a procedure would minimize the "surprise" value of the stimuli and this is identical with minimizing perceptual load.

In order to follow the argument it may be helpful if the reader visualizes the kind of stimulus material we are considering and which was used in the experiments to be described. Suppose dot patterns are given in a rapid succession of presentations, as could be achieved by using cine-film. A particular pattern, say a square of four dots, could be presented and it could then be "disturbed" by added noise. The location of each corner of the square might for instance be specified by a bivariate normal distribution. The mean of this distribution would coincide with the correct position of 
the corner of the square, but in any particular presentation the dot would depart somewhat from this exact position, to an extent dependent on the variance of the distribution. Thus a succession of patterns looking like distorted squares would be presented.

Are subjects able to recognize the square in such a sequence of distorted presentations? If they succeeded, the surprise value of the later stimuli in the sequence would be minimized. Perception would then show efficient coding in the sense used by Attneave (1954). Instead of perceiving a whole series of different patterns the subject would see a steady pattern as a first component, and the second component would be seen as a "quivering" of the first.

This kind of perceptual task is found in many real cases, for instance in radars, where the operator has to identify the track of the moving object from a succession of signals on the screen. Here some noise is practically always to be expected; noise resulting from the working of the apparatus itself, or from the fact that the scanning beam picks up an echo from different parts of the object in successive rotations. An object moving along a straight line appears on the screen as a zigzagging of discrete dots.

There are a number of problems to be solved in dealing with this kind of stimulus material.

(I) The first problem is the difficulty of defining the subject's response. People appear to perceive this sort of stimulus material in a variety of ways, and if they are left to describe freely "what they see," such descriptions are so divergent that they cannot be used to measure or test anything. There are two possible solutions, to have subjects learn a particular kind of response or to restrict the range of free responses. In the first case one attempts to have the subject attend to a particular aspect of the stimulus material, in the second kind one forces him to produce a particular kind of response. In both procedures the original "richness" of perception will be to some extent hidden from the experimenter. Careful questioning could, of course, reveal anything we might be interested in but it is felt that in the present experiments the difficulty of response specification is far from being resolved.

(2) The second problem concerns the nature of the coding system used by the subject. It is clear that our perception of a rapid sequence of random patterns can only be in rather global terms. The sequence of stimuli is certainly not wholly reproducible and it follows that ones which are actually different in all their details, might appear very similar to the subject. This indicates that the subject is performing some kind of coding: sequences which are seen as similar, or where the subject cannot specify the difference or where he perceives them as instances of the same general prototype, are coded in the same way. What is the most effective form of coding, and what is it the subject picks out of this kind of stimulus material?

(3) The third problem is the one mentioned above: are subjects able to separate stochastic and fixed components? Are they able to recognize the parameters behind the stochastic production of patterns?

\section{The EXPeriments}

A number of preliminary experiments showed that subjects have extreme difficulty in detecting characteristics of stimulus sequences when these characteristics are masked by noise, in the sense described above. Speaking in statistical terms one may say that human perceivers are extremely prone to type II errors: they maintain the nullhypothesis even if there is abundant evidence against it according to statistical criteria. This negative result was partly responsible for the design of the following main experiments. It was decided to use a recognition method, in order to give the subjects the best chance of revealing any capacities they might have after all —and second, Osgood's semantic 
scaling technique was chosen for the same reason, and also to gather some hints as to which categories might be effective in perception.

\section{Material}

The experimental material consisted of $4^{\mathrm{I}}$ film strips each with $4^{\circ}$ opaque frames. Each frame contained one hole, located somewhere in an $18 \times 18$ matrix. (The holes were made in the film by punching through selected holes in a metal template.) The strips were

\section{FIGURE I}
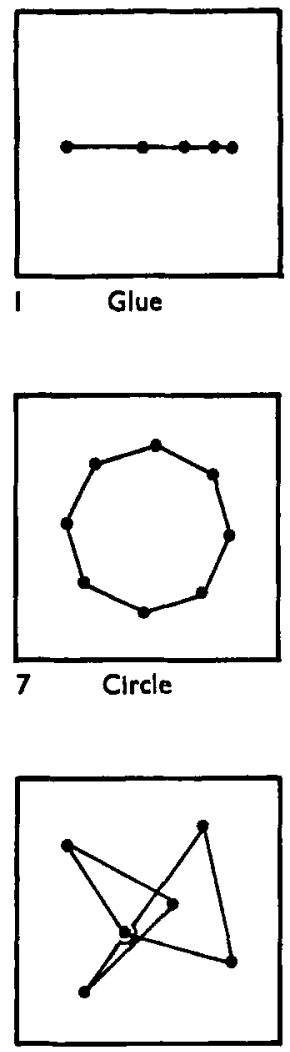

II Helix

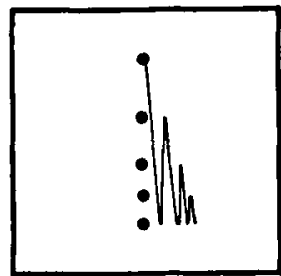

2 Bouncer

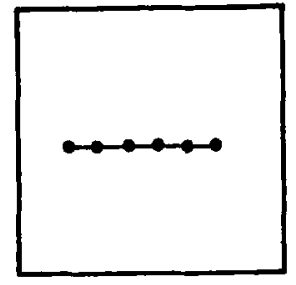

8 Horizontal six

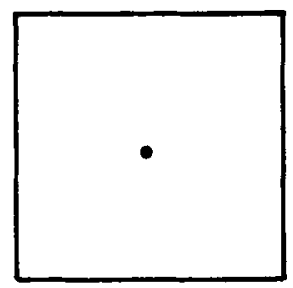

$12 \quad$ Point $\rightarrow$

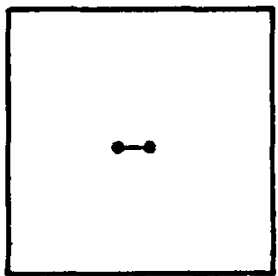

5 Horizontal two

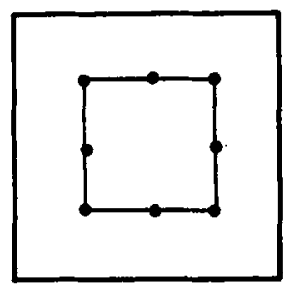

9 Square eight

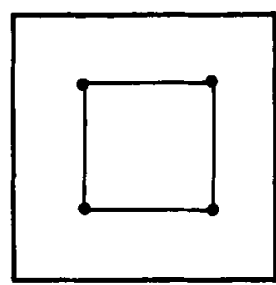

13 Square four

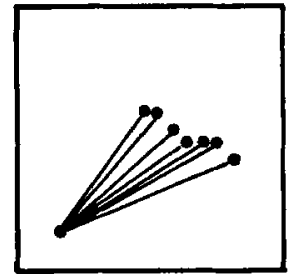

Fan
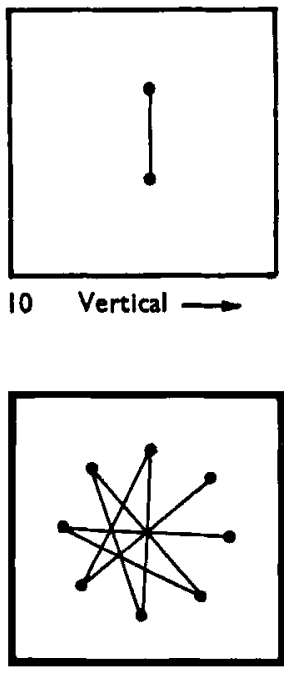

$15 \quad$ Star

The I 2 patterns used in the semantic rating and the pattern-recognition experiments. Pattern 3 was the Brownian variant of ro ("Brownian dance"), pattern 4 was the Brownian variant of 12 ("Brownian movement") and 14 was the bivariate rectangular density distribution.

shown by means of a slowed-down cine projector at a rate chosen to facilitate the appearance of stroboscopic movement. The white spot projected on to a $90 \times 90 \mathrm{~cm}$. screen thus moved to a series of positions describing a chosen pattern, such as a square, horizontal straight line, or circle.

Fourteen patterns were used of which 12 are shown in Figure 1 , the numbers at each position indicating the order of presentation. The patterns were given arbitrary names, as shown above.

The patterns could be shown either in pure or noisy form. Noise was introduced by displacing each dot a random distance from its proper position in the matrix. Horizontal and vertical displacements were random normal deviates with zero mean and variance 
I.64 (Level I) or 3.03 (Level 2) matrix units. The effect of the "noise" was that the patterns shown in Figure I appeared on the screen either less or more distorted.

The use of 12 patterns at three noise levels (zero, I and 2) accounts for 36 strips. Noise can also be added in a different way, by locating the mean of the bivariate distribution at the last position of the dot instead of at a fixed position. This procedure was applied to patterns I2 and Io, resulting in a kind of Brownian motion of a single dot, and in a Brownian dance of two dots respectively. The previous two levels of variance were used, giving 4 strips. The series of $4 \mathrm{I}$ was completed by presenting a single dot located at random in bivariate rectangular distribution.

A third experimental variable was rate of presentation; fast or slow, corresponding to 2 and I presentations per sec. respectively. To economise in time rate was not varied for all the patterns. The final arrangement is shown in Table I, the numbers in the cells referring to the order of presentation of the $4^{\mathrm{I}}$ series in the recognition experiment.

TABLE I

The Order of Presentation of the 4I Filmstrips This order was reversed for the second group in experiment II

\begin{tabular}{|c|c|c|c|c|c|c|c|c|c|c|c|c|c|c|c|}
\hline Pattern & $\mathbf{I}$ & 2 & 3 & 4 & 5 & 6 & 7 & 8 & 9 & ro & II & 12 & 13 & 14 & r5 \\
\hline Noise Level 2 & I6 & 2 & 29 & I9 & 30 & 10 & 25 & 12 & II & 33 & 13 & 37 & $3^{8}$ & \multirow{3}{*}{34} & 39 \\
\hline$\Rightarrow \quad I$ & 4 & 6 & 20 & I7 & 23 & $3^{I}$ & $4^{I}$ & 24 & $2 I$ & 28 & 8 & 26 & 14 & & 35 \\
\hline . 0 & 9 & $3^{6}$ & & & $\mathbf{I}$ & 15 & 7 & 18 & 32 & 40 & 3 & 5 & 22 & & 27 \\
\hline
\end{tabular}

\section{Semantic Rating EXPERIMENT I}

\section{Procedure}

Subjects were given a list of 19 semantic scales of the Osgood type, each with 7 positionsThey are given in Table II, except for Scale I2 (centrifugal-centripetal) which was dis. carded for lack of discrimination.

The subjects were $3 \mathbf{I}$ psychology undergraduates in the University of Leiden. They were divided into two groups and each group had to rate the films on ro scales (Scale 3 was made common to both in order to have some check on inter-group reliability; a correlation of $r=0.94$ was obtained).

\section{Results}

The ratings were factor-analysed by the centroid method and the results are given in Table II. The factors were rotated to new orthogonal positions according to a cluster inspection (no simple structure was evident, and it is not theoretically expected since the scales are not supposed to represent an unbiased sample from the universe of categories). The loadings on the rotated factors are also given in Table II. The factors may be tentatively labelled on the basis of the loadings as follows:factor I-(heavy, slow, dull, passive)- "rate";

factor II-(determined, even, symmetrical, stable)- "regularity"; factor III-(closed, beautiful, round)-"gestalt."

Inspection of the strips of patterns with high or low factor scores revealed that factor I discriminates between the slow films and the fast ones with no overlap and it thus appears to have a clear denotative meaning. 
Factor II appears to distinguish between noiseless and noisy patterns. Table III gives factor score estimates. The noiseless patterns scored significantly higher than the noisy ones $(p<0.01)$ and the patterns with low-level noise scored higher than those with high-level noise $(p<0.05)$. Therefore factor II also has a clear denotation.

Factor III has some connection with noise but not at a significant level. The scales which are highly loaded on this factor apparently refer to characteristics of the

TABLE II

(a) Factor Loadings of Scales Before and After Rotation

\begin{tabular}{|c|c|c|c|c|c|c|c|}
\hline \multirow[b]{3}{*}{ Scales } & \multirow{2}{*}{\multicolumn{3}{|c|}{ Raw loadings }} & \multirow[b]{3}{*}{$h^{2}$} & \multicolumn{3}{|c|}{ After rotation } \\
\hline & & & & & \multirow{2}{*}{ Factor I } & \multirow{2}{*}{$\begin{array}{c}\text { Factor II } \\
\text { "regu- } \\
\text { larity" }\end{array}$} & \multirow{2}{*}{$\begin{array}{c}\text { Factor III } \\
\text { "gestalt" }\end{array}$} \\
\hline & $I$ & $I I$ & $I I I$ & & & & \\
\hline I. Closed-Open .. & 428 & 561 & -406 & 663 & -183 & $45 \mathrm{I}$ & 650 \\
\hline 2. Heavy-Light .. & 757 & -574 & -152 & 926 & 884 & $\begin{array}{l}421 \\
371\end{array}$ & 082 \\
\hline 3. Evenly-Varying & 890 & 228 & 289 & 928 & I7 I & 948 & - oI6 \\
\hline 4. Beautiful-Ugly & 419 & 671 & -182 & 659 & -330 & 562 & 481 \\
\hline 5. Determined-Random & $84 I$ & $52 \mathrm{r}$ & 033 & 980 & -046 & 936 & 312 \\
\hline 6. Passive-Active & 874 & $-43^{\circ}$ & 020 & 949 & $78 \mathrm{I}$ & 585 & -003 \\
\hline 7. Round-Angular & 493 & 051 & -355 & 372 & 270 & 323 & 437 \\
\hline 8. Slow-Fast & 709 & $-5^{67}$ & -253 & 888 & 877 & 299 & 168 \\
\hline $\begin{array}{c}\text { 9. Is displaced-Moves } \\
\text { itself .. .. }\end{array}$ & $67 I$ & $-I_{4} 6$ & -170 & 500 & 483 & 460 & 232 \\
\hline Io. Dull-Vivid .. & 879 & -439 & -056 & 968 & 807 & $56 I$ & 065 \\
\hline II. Poor-Rich & 712 & -268 & 267 & 650 & 512 & 593 & -203 \\
\hline I3. Stable-Labile.. & 837 & 280 & $33^{6}$ & 892 & $09 \mathrm{I}$ & 939 & $-05 I$ \\
\hline $\begin{array}{c}\text { I4. Symmetrical-Asym- } \\
\text { metrical }\end{array}$ & 815 & 529 & -069 & 949 & -043 & 883 & 403 \\
\hline 15. Rigid-Resilient & 754 & -275 & 350 & 767 & 520 & 654 & -274 \\
\hline $\begin{array}{l}\text { 16. Easy to follow- } \\
\text { Difficult to follow }\end{array}$ & 834 & 248 & -107 & 769 & 213 & 776 & \\
\hline 17. Tied-Free & 918 & 219 & 207 & 934 & 210 & 941 & $\begin{array}{l}343 \\
061\end{array}$ \\
\hline I8. Always the same point- & & & & & & & \\
\hline More different points & $82 \mathrm{I}$ & I 78 & 254 & $77^{\circ}$ & I 88 & $85^{8}$ & -015 \\
\hline I9. Weak-Strong.. & 375 & -774 & $07 \mathbf{I}$ & 745 & 822 & 040 & -265 \\
\hline
\end{tabular}

(b) Rotation Matrix

\begin{tabular}{r|r|r|r}
\hline & \multicolumn{1}{|c|}{$I$} & $I I$ & \multicolumn{1}{|c}{$I I I$} \\
\cline { 2 - 4 } I & $4^{80}$ & 856 & 190 \\
II & -850 & 394 & 350 \\
III & -2 I7 & 335 & -917 \\
\hline
\end{tabular}

patterns themselves, and it is found that the patterns with high estimates in factor III are more "complex" and have more "spread"; they include spots at more widely spaced positions in the matrix - as against ones at only a few or more closely spaced positions.

\section{Procedure}

\section{Pattern Recognition-Experiment II}

The strips were shown in the same way as in the previous experiment, but the rate was kept constant at two presentations per second. Subjects were instructed to identify each pattern from 15 alternatives, which were presented as in Figure I (unnumbered) together with the Brownian motion, dance, and rectangular random motion. Care was taken to explain the meaning of the pictures, and the nature of "disturbance by noise." That subjects understood the instructions and used the pictures properly, was apparent from 
the fact that they recognized the noiseless patterns correctly with two exceptions to be explained later. (French (1954) used an interesting technique to overcome the difficulty of instructions.)

Subjects were allowed to choose more than one pattern if they felt that they could not decide among them. The number of responses per strip was therefore not constant.

The 24 undergraduates appeared to enjoy the task, in striking contrast to the impression gained in the semantic rating experiment. They were tested in two group sessions, the order of presentation being balanced by reversing the order given in Table I for the second group.

\section{TABLE III}

Factor Score Estimates and the Drop in Factor II on AdDition of Notse

\begin{tabular}{|c|c|c|c|c|c|c|c|c|}
\hline \multirow{3}{*}{$\frac{\text { Noise }}{\text { Pattern }}$} & \multicolumn{3}{|c|}{$\begin{array}{c}\text { Pattern scores on factor II } \\
\quad \text { (in standard scores })^{*}\end{array}$} & \multicolumn{3}{|c|}{$\begin{array}{l}\text { Pattern scores on factor III } \\
\quad \text { (in standard scores })^{* *}\end{array}$} & \multicolumn{2}{|c|}{$\begin{array}{l}\text { Drop in factor II } \\
\text { when noise is added }\end{array}$} \\
\hline & \multirow{2}{*}{$0.00(0)$} & \multirow{2}{*}{$I \cdot 64(I)$} & \multirow{2}{*}{$3.03(2)$} & \multirow{2}{*}{$0.00(0)$} & \multirow{2}{*}{$I \cdot 64(I)$} & \multirow{2}{*}{$3.03(2)$} & \multirow{2}{*}{$(0)-(\mathrm{I})$} & \multirow{2}{*}{$(0)-(2)$} \\
\hline & & & & & & & & \\
\hline I & $I \cdot 44$ & -0.49 & -0.85 & $-0 \cdot 12$ & 0.37 & $-0.2 \mathrm{I}$ & $I \cdot 39$ & $2 \cdot 29$ \\
\hline 2 & $0.6 \mathrm{I}$ & -0.87 & $-I \cdot I I$ & 0.16 & $-0.8 \mathrm{I}$ & -0.90 & $\mathrm{I} \cdot 48$ & $I \cdot 72$ \\
\hline 3 & - & -0.08 & -0.75 & - & $-I \cdot 04$ & $-0.4^{6}$ & - & - \\
\hline 4 & - & -0.79 & $-1 \cdot 09$ & - & -0.37 & $-0.5 I$ & - & 一 \\
\hline 5 & I. 55 & -0.56 & -0.72 & $-0.8 I$ & $-I \cdot 39$ & -0.56 & $2 \cdot I I$ & $2 \cdot 22$ \\
\hline 6 & 0.96 & $-0 . \mathbf{I}$ I & 0.00 & $-I \cdot 5^{8}$ & -1.07 & -0.51 & $I \cdot 07$ & $0 \cdot 96$ \\
\hline 7 & $1 \cdot 44$ & $0.7 \mathrm{I}$ & -0.03 & $2 \cdot 44$ & $I \cdot 72$ & $\mathrm{I} \cdot 95$ & 0.73 & $I \cdot 47$ \\
\hline 8 & $x \cdot 76$ & -0.90 & $-1 \cdot 27$ & -0.63 & 0.16 & -0.44 & $2 \cdot 66$ & 3.03 \\
\hline 9 & $I \cdot 3 I$ & $0.2 \mathrm{I}$ & -0.39 & $\mathrm{I} \cdot 5 \mathrm{I}$ & $2 \cdot 67$ & I. 55 & I. IO & $I \cdot 70$ \\
\hline 10 & 1.88 & $-0 \cdot 16$ & -0.04 & $-0 \cdot 19$ & -0.93 & 0.09 & $2 \cdot 04$ & $I \cdot 92$ \\
\hline II & -0.34 & $-I .20$ & $-I \cdot 20$ & -0.49 & 0.39 & -0.19 & 0.86 & 0.86 \\
\hline 12 & $1 \cdot 69$ & $-I \cdot 10$ & -0.86 & -0.77 & -0.35 & -0.74 & $2 \cdot 79$ & $2 \cdot 55$ \\
\hline I3 & $1 \cdot 76$ & 0.87 & $-0.7^{2}$ & $0 \cdot 35$ & 0.88 & $0.2 \mathrm{I}$ & 0.89 & $\mathrm{I} \cdot \mathrm{O}_{4}$ \\
\hline I4 & - & -0.159 & - & - & -0.65 & - & - & - \\
\hline 15 & 0.52 & -0.18 & -0.79 & $I \cdot I 8$ & -0.23 & $-0.5 I$ & 0.70 & $I \cdot 31$ \\
\hline
\end{tabular}

- Factor II-scores are obtained by adding scores on scales, 5, I3 and 14.

** Factor III-scores are obtained by adding scores on scales $I$ and 7 , and subtracting score on scale 15 .

\section{Results}

The raw results (given in Table IV) are not very revealing, and we have devised a measure of stimulus "confusion"-

$$
c_{p q}=\Sigma f_{i p} \cdot f_{1 q} /\left(\Sigma f_{1 p^{2}} \cdot \Sigma f_{1 q}\right)^{\xi}
$$

where $c_{p q}$ is the "confusion" between stimuli $p$ and $q$, and $f_{1 p}$ is the frequency of choice of alternative $i$ when stimulus $p$ was presented.

The measure can be visualized as follows. A response distribution can be represented as a point in a I5-dimensional space, the coordinate in each dimension representing the frequency of choice of one response alternative, and $c_{p q}$ represents the cosine of the angle between the vectors for stimuli $p$ and $q$ in response space. It is a kind of correlation measure, and the matrix of confusion values may suggest the presence of "factors" in response space.

The measure is not statistically sound, since the sampling distribution is unknown. However, chi-square applied to cell frequencies would fail since the cell entries are often very small and the exact probability approach would have been too timeconsuming. Apart from the unknown sampling distribution, the measure disregards 
TABLE IV

Responses given on Presentation of Various Patterns

\begin{tabular}{|c|c|c|c|c|c|c|c|c|c|c|c|c|c|c|c|c|}
\hline $\begin{array}{c}\text { Pattern } \\
\text { presented }\end{array}$ & Noise & 2 & IO & 3 & $\mathbf{I}$ & 4 & 5 & 8 & 12 & 6 & 7 & 9 & I I & 13 & $I_{4}$ & I5 \\
\hline 2 & $\begin{array}{l}0 \\
I \\
2\end{array}$ & $\begin{array}{r}79 \\
28 \\
6\end{array}$ & 3 & $\begin{array}{r}5 \\
13 \\
22\end{array}$ & & $\begin{array}{l}1 \\
6\end{array}$ & & & & $\begin{array}{l}2 \\
2\end{array}$ & & I & I 2 & & $\begin{array}{r}5 \\
10\end{array}$ & 3 \\
\hline IO & $\begin{array}{l}0 \\
1 \\
2\end{array}$ & $\begin{array}{r}4 \\
\text { I3 } \\
\text { I I }\end{array}$ & $\begin{array}{r}87 \\
3\end{array}$ & $\begin{array}{r}3 \\
34 \\
35\end{array}$ & & $\begin{array}{r}3 \\
34 \\
35\end{array}$ & & & & & $\begin{array}{l}2 \\
2\end{array}$ & 2 & $\begin{array}{l}3 \\
4\end{array}$ & & $\begin{array}{l}2 \\
2\end{array}$ & \\
\hline 3 & $\begin{array}{l}\mathbf{I} \\
\mathbf{2}\end{array}$ & $\begin{array}{l}20 \\
12\end{array}$ & & $\begin{array}{l}33 \\
17\end{array}$ & 5 & $\begin{array}{l}3 \\
3\end{array}$ & & & & & & & 8 & & $\begin{array}{r}4 \\
15\end{array}$ & 2 \\
\hline I & $\begin{array}{l}0 \\
1 \\
2\end{array}$ & $\begin{array}{l}4 \\
\mathrm{I}\end{array}$ & & $\begin{array}{r}8 \\
17\end{array}$ & $\begin{array}{l}35 \\
22 \\
12\end{array}$ & $\begin{array}{r}13 \\
6\end{array}$ & & $\begin{array}{r}54 \\
2 \\
1\end{array}$ & 3 & $\begin{array}{l}\mathbf{I} \\
\mathbf{I}\end{array}$ & $\mathbf{I}$ & $\begin{array}{l}4 \\
\mathrm{I} \\
2\end{array}$ & $\begin{array}{l}2 \\
I\end{array}$ & & $\begin{array}{l}8 \\
2\end{array}$ & \\
\hline 4 & $\begin{array}{l}\mathbf{I} \\
\mathbf{2}\end{array}$ & $\begin{array}{r}7 \\
12\end{array}$ & & $\begin{array}{l}8 \\
5\end{array}$ & 3 & $\begin{array}{l}19 \\
18\end{array}$ & & 2 & & 2 & 2 & & & I & $\begin{array}{l}3 \\
6\end{array}$ & \\
\hline 5 & $\begin{array}{l}0 \\
\text { I } \\
2\end{array}$ & I & & $\begin{array}{r}6 \\
\text { I I }\end{array}$ & $\begin{array}{l}4 \\
7 \\
4\end{array}$ & $\begin{array}{l}\text { I3 } \\
\text { I9 }\end{array}$ & $\begin{array}{r}93 \\
\text { I } \\
\text { I }\end{array}$ & & I & $\begin{array}{l}6 \\
5\end{array}$ & & & I & & $\begin{array}{l}\mathbf{I} \\
3\end{array}$ & 2 \\
\hline 8 & $\begin{array}{l}0 \\
I \\
2\end{array}$ & $\begin{array}{l}2 \\
4\end{array}$ & & $\begin{array}{l}\text { I I } \\
\text { I0 }\end{array}$ & $\begin{array}{r}8 \\
15 \\
12\end{array}$ & $\begin{array}{r}8 \\
20\end{array}$ & & $\begin{array}{r}80 \\
5\end{array}$ & & $\begin{array}{l}2 \\
I\end{array}$ & $\begin{array}{l}\mathbf{I} \\
3\end{array}$ & & & & $\begin{array}{l}2 \\
7\end{array}$ & I \\
\hline 12 & $\begin{array}{l}0 \\
I \\
2\end{array}$ & $\begin{array}{l}6 \\
\mathrm{I}\end{array}$ & I & $\begin{array}{r}1 \\
19 \\
8\end{array}$ & $\begin{array}{r}2 \\
14\end{array}$ & $\begin{array}{l}\text { I5 } \\
21\end{array}$ & I & $\begin{array}{l}I \\
2\end{array}$ & 88 & 3 & & $\mathbf{I}$ & $\begin{array}{l}\text { I } \\
2\end{array}$ & I & $\begin{array}{l}1 \\
3\end{array}$ & I \\
\hline 6 & $\begin{array}{l}0 \\
1 \\
2\end{array}$ & $\begin{array}{l}2 \\
3 \\
2\end{array}$ & $\begin{array}{l}5 \\
\text { I }\end{array}$ & $\begin{array}{l}4 \\
I \\
2\end{array}$ & 3 & I & & & & $\begin{array}{l}71 \\
35 \\
49\end{array}$ & 3 & & $\begin{array}{l}\mathbf{I} \\
\mathbf{I}\end{array}$ & & 2 & $\begin{array}{l}6 \\
6\end{array}$ \\
\hline 7 & $\begin{array}{l}0 \\
1 \\
2\end{array}$ & & & & & & & & & 7 & $\begin{array}{l}91 \\
55 \\
10\end{array}$ & $\begin{array}{l}6 \\
6\end{array}$ & 9 & & $\begin{array}{r}3 \\
20\end{array}$ & $\begin{array}{r}4 \\
5 \\
\text { I0 }\end{array}$ \\
\hline 9 & $\begin{array}{l}0 \\
\text { I } \\
2\end{array}$ & & & 2 & & 2 & I & 2 & 4 & $\begin{array}{l}8 \\
2\end{array}$ & $\begin{array}{r}28 \\
7\end{array}$ & $\begin{array}{r}84 \\
7 \\
4\end{array}$ & $\begin{array}{r}6 \\
\text { II }\end{array}$ & & $\begin{array}{r}9 \\
13\end{array}$ & $\begin{array}{r}7 \\
\text { 10 }\end{array}$ \\
\hline I I & $\begin{array}{l}0 \\
1 \\
2 \\
\end{array}$ & I & 3 & & & $\mathbf{I}$ & & & & 2 & & $\begin{array}{l}4 \\
4 \\
\end{array}$ & $\begin{array}{l}4^{8} \\
47 \\
3^{8} \\
\end{array}$ & $\begin{array}{l}\text { I } \\
I\end{array}$ & $\begin{array}{l}\text { I I } \\
\text { I I } \\
\text { I } 5 \\
\end{array}$ & $\begin{array}{l}\text { I } \\
7 \\
5 \\
\end{array}$ \\
\hline I3 & $\begin{array}{l}0 \\
\text { r } \\
2\end{array}$ & & 3 & & & 3 & & & & & $\begin{array}{r}2 \\
10\end{array}$ & $\begin{array}{l}9 \\
9\end{array}$ & $\begin{array}{r}\text { I0 } \\
9\end{array}$ & $\begin{array}{l}95 \\
34 \\
22\end{array}$ & IO & 3 \\
\hline 14 & & & & 2 & & 2 & & & & & & I & I 4 & & $4^{8}$ & \\
\hline I5 & $\begin{array}{l}0 \\
\text { I } \\
2\end{array}$ & I & & & & I & & & & & 2 & $\begin{array}{l}7 \\
2\end{array}$ & $\begin{array}{l}8 \\
6\end{array}$ & & $\begin{array}{r}4 \\
8 \\
18\end{array}$ & $\begin{array}{l}75 \\
47 \\
27\end{array}$ \\
\hline
\end{tabular}

Subjects were allowed to indicate as many patterns as they liked. Moreover they stated the judged degree of similarity to the pattern on a scale-

$$
\begin{aligned}
& 4 \text { exactly this pattern, } \\
& 3 \text { this pattern, but not exactly, } \\
& 2 \text { it looks like this pattern, } \\
& \text { I maybe it is this pattern. }
\end{aligned}
$$

The cell values are sums of these confidence ratings given by all subjects. 
TABLE $\mathrm{V}$

Calculated Confusion Between Patterns (Clusters Indicated)

(a) Confusion between noiseless patterns (including pattern I4)

\begin{tabular}{|c|c|c|c|c|c|c|c|c|c|c|c|c|}
\hline & Io & I & 5 & 8 & I 2 & 6 & 7 & 9 & I I & I 3 & I5 & I4 \\
\hline $\begin{array}{r}2 \\
10\end{array}$ & 08 & & \multirow{9}{*}{02} & \multirow{9}{*}{88} & & \multirow[t]{9}{*}{$0_{4}$} & \multirow{9}{*}{02} & \multirow{9}{*}{ o6 } & $\begin{array}{l}\text { OI } \\
\text { OI }\end{array}$ & & \multirow{5}{*}{02} & or \\
\hline I & & & & & & & & & & & & \multirow[t]{3}{*}{ o] } \\
\hline $\begin{array}{l}5 \\
8\end{array}$ & & & & & & & & & & & & \\
\hline I 2 & & & & & & & & & & & & \\
\hline 6 & & & & & & & & & OI & & & \\
\hline $\begin{array}{l}7 \\
9\end{array}$ & & & & & & & & & o8 & & 01 & $\begin{array}{l}07 \\
\text { ro }\end{array}$ \\
\hline II & & & & & & & & & & & 49 & 02 \\
\hline I3 & & & & & & & & & & & & 05 \\
\hline I5 & & & & & & & & & & & & \\
\hline
\end{tabular}

(b) Confusion between patterns with noise level $\mathbf{I}$.

\begin{tabular}{|c|c|c|c|c|c|c|c|c|c|c|c|c|c|}
\hline & Io + & $3+$ & $\mathbf{I}+$ & $4+$ & $5+$ & $8+$ & $12+$ & $6+$ & $7+$ & $9+$ & $\mathbf{I I}+$ & $1_{3}+$ & $15+$ \\
\hline $2+$ & 69 & 73 & 30 & $4^{8}$ & 20 & 32 & 56 & 16 & or & 08 & 04 & or & 03 \\
\hline 10 + & & 83 & $4^{2}$ & 64 & $5^{I}$ & 59 & 9I & 08 & OI & 08 & 09 & 04 & 02 \\
\hline $3+$ & & & 40 & $4^{8}$ & 36 & 52 & 71 & 08 & or & 07 & 03 & oo & 06 \\
\hline $1+$ & & & & 68 & 79 & 93 & 59 & I6 & 06 & 18 & 13 & oo & 06 \\
\hline $4+$ & & & & & 86 & 65 & 87 & 19 & ro & I 5 & $0_{4}$ & oo & 02 \\
\hline $5+$ & & & & & & 79 & 79 & 43 & OI & I I & II & 03 & 13 \\
\hline $8+$ & & & & & & & 71 & 20 & 05 & I3 & 03 & $\infty$ & 06 \\
\hline $12+$ & & & & & & & & 20 & OI & 08 & 06 & 06 & 02 \\
\hline $6+$ & & & & & & & & & Io & I8 & 09 & 03 & 17 \\
\hline $7+$ & & & & & & & & & & 92 & 02 & 08 & I0 \\
\hline $9+$ & & & & & & & & & & & & I6 & 29 \\
\hline $\mathbf{I I}+$ & & & & & & & & & & & & 27 & 35 \\
\hline I3 + & & & & & & & & & & & & & I4 \\
\hline
\end{tabular}

(c) Confusion between patterns with noise level $\mathrm{s}$.

\begin{tabular}{|c|c|c|c|c|c|c|c|c|c|c|c|c|c|}
\hline & rot+ & $3++$ & $\mathbf{I}++$ & $4++$ & $5++$ & $8++$ & $12++$ & $6++$ & $7++$ & $9++$ & $\mathrm{II}++$ & $\mathrm{r}_{3}++$ & $\mathrm{I}_{5}++$ \\
\hline $2++$ & 86 & 92 & 72 & 53 & $6 r$ & $5^{8}$ & $4^{8}$ & 12 & 44 & 49 & 53 & 27 & 43 \\
\hline ro ++ & & 79 & 76 & 39 & 50 & 45 & 33 & 49 & Io & II & 12 & 07 & 14 \\
\hline $3++$ & & & 59 & 59 & $4^{8}$ & 52 & 37 & 05 & 50 & 50 & $4^{8}$ & 29 & $4 I$ \\
\hline $\mathbf{I}++$ & & & & 43 & 71 & $7^{8}$ & 75 & 07 & II & 12 & $\infty 9$ & Io & 12 \\
\hline $4++$ & & & & & 80 & 80 & 73 & 03 & I9 & 23 & 12 & 20 & 16 \\
\hline $5++$ & & & & & & 92 & 89 & 23 & 15 & 0 & 07 & 13 & 17 \\
\hline $8++$ & & & & & & & 96 & 06 & 23 & 20 & I I & 20 & 18 \\
\hline $\mathbf{I 2}++$ & & & & & & & & 02 & 12 & 0 & 14 & I5 & 14 \\
\hline $6++$ & & & & & & & & & 30 & 07 & 04 & OI & II \\
\hline $7++$ & & & & & & & & & & 90 & 63 & 54 & 74 \\
\hline $9++$ & & & & & & & & & & & 77 & 54 & 80 \\
\hline $\mathbf{I} \mathbf{I}++$ & & & & & & & & & & & & $4^{6}$ & $4^{6}$ \\
\hline $\mathbf{1 3}++$ & & & & & & & & & & & & & 24 \\
\hline
\end{tabular}


the dimensionality of response space so that the real dimensions are not equally weighted.

The calculated values of $c_{p q}$ are given in Table $V$ which shows that noiseless patterns are well recognized $\left(c_{p q}=0\right.$ if there is no overlap between the response distributions; $c_{p q}=I$ if they are identical). The two exceptions are readily explained: subjects take pattern I as the random variant of 8 , II as an instance of I4. Errors of this kind can be easily prevented if noiseless and noisy patterns are not intermingled in the same series.

In order to examine the degree to which different patterns resist noise, one should inspect the diagonal cell entries, which are given in Table VI.

TABLE VI

Confusion Between Patterns shown Noiseless and wrth NOISE AT LEVEL I OR LEVEL 2

\begin{tabular}{cc|c|c|c|c|c|c|c|c|c|c|c|c}
\hline & & $I$ & 2 & 5 & 6 & 7 & 8 & 9 & I0 & II & I2 & I3 & I5 \\
\hline Noise level-1 &. & $4^{8}$ & 92 & 07 & 96 & 99 & 30 & 22 & I3 & 99 & OI & 92 & 98 \\
Noise level-2 &. & 34 & 26 & 05 & 99 & $3^{8}$ & 04 & 19 & 05 & 99 & 00 & 75 & 84 \\
\hline
\end{tabular}

Ideally a noiseless pattern should be entirely confused with its noisy variants. High values in Table VI therefore indicate that the pattern is relatively noiseproof and low values the reverse. We see, that 6 (fan), II (helix), I3 (square four), and I5 (star) are relatively noiseproof, whereas I (glue), 5 (horizontal two), 8 (horizontal

FIGURE 2
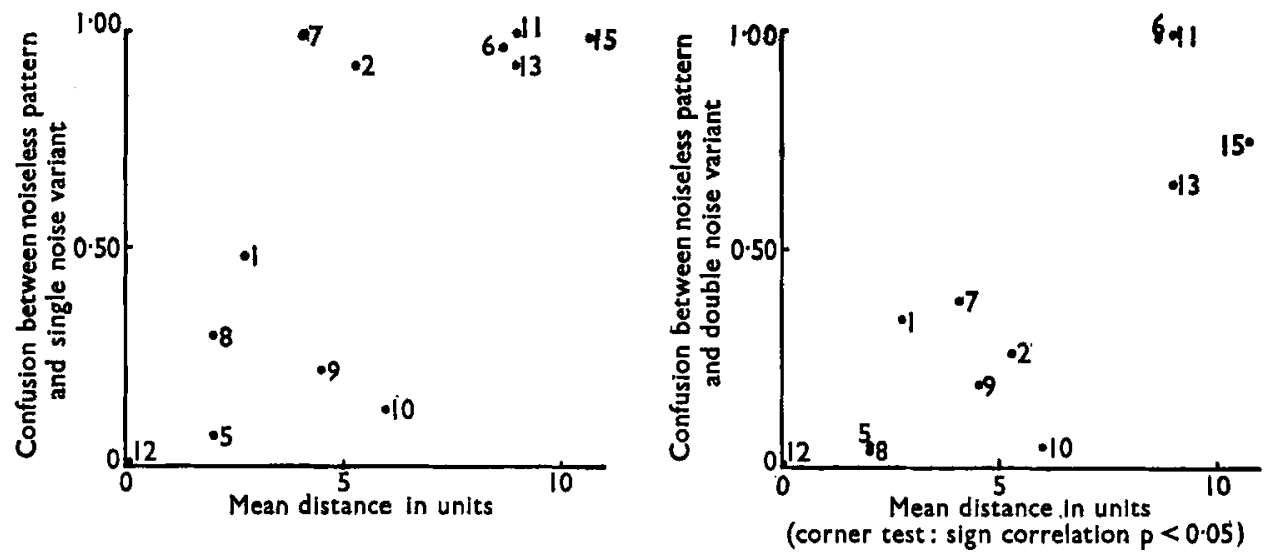

Mean intrapattern distance explains the vulnerability of patterns to noise (data of Table V).

six), 9 (square eight), Io (vertical), I2 (point) are vulnerable. The explanation is simple: in the noiseproof patterns the average distance travelled by the dot between successive frames is high $\left(8.7,9^{\circ} 0,9^{\circ} 0,10 \cdot 7\right.$ units, respectively), whereas in the vulnerable patterns it is small $(2 \cdot 75,2 \cdot 0,2 \cdot 0,4 \cdot 5,6 \cdot 0$, and $0 \cdot 0)$. Two patterns, 2 (bouncer) and 7 (circle), resist a low level of noise, but are vulnerable to a high level; the mean intrapattern distance here is 5.3 and 4.1 units. Figure 2 shows this result graphically. 
On inspection the confusion matrices reveal the presence of several clusters, (I) patterns, I, 3, 4, 5, 8 and I 2 ; (2) patterns, 2, 3 and Io; and (3) 7,9, II, I3, I4 and I5; (4) pattern 6 appears to stand alone.

These "confusion groups" reveal the kind of coding subjects use. The common feature within each group gives an indication of the idea of pattern similarity the subjects might have. We find that group (I) is characterized by horizontal patterns (glue, Brownian dance, Brownian movement, horizontal 2, horizontal 6, point), group (2) by vertical patterns (bouncer, Brownian dance, vertical) and group (3) by extension or spread of pattern (circle, square 8, helix, square 4, star). (4) Pattern 6 (fan) does not clearly belong to any of these groups; pattern 3 (Brownian dance) is mainly a vertical pattern, but the film creates an impression of horizontal motion also. Groups (I) and (2) are actually linked whereas group (3) is separate.

One may conclude that subjects "regress" to very general spatial orientation when identifying noisy patterns. It may once again be stressed that the noisy patterns are

\section{FIGURE 3}
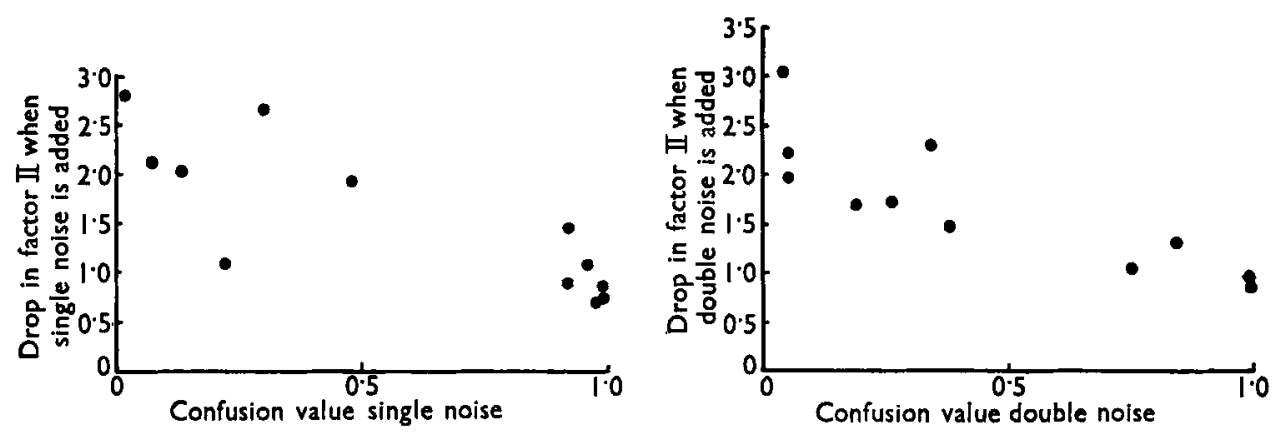

Noise resistant patterns (Table V) show smaller drop in factor II if noise is added (Table III), than do vulnerable patterns.

easily discriminable by an ideal detector; since subjects fall so far behind this ideal detector, it shows that they are unable to apply Bayes' theorem in an efficient way.

\section{Discussion of combined results}

(I) Since rate of presentation was not varied in the recognition experiment, and since semantic factor I was connected with rate, this factor can be left out of further consideration.

(2) Factor II appeared to refer to "noisiness" of the strips. Table VI indicates which patterns are noise-resistant, and this measure should be related in some way to semantic factor II. Specifically, noise-resistant patterns should show a smaller drop in factor II if noise is added, than vulnerable patterns.

This expectation is borne out, according to Figure 3 where the drop in factor II (Table III) is plotted against the confusion value from Table VI. A simple corner test shows that the relation is significant at the I per cent. level. There is another way to show the relation between factor II and confusion. The mean of all its confusion values in the matrix (Table VII) is an index of the general confusability of a given stimulus. If these means (via $z$ - transformation) are taken for the levels of matrix and plotted against the drop in factor II, we again find a significant relationship; for noise level $\mathrm{I}$ the relation is as good as one might wish (Fig. 4). 
TABLE VII

Mean Confusion Values (General Confusability)

\begin{tabular}{ll|c|c|c|c|c|c|c|c|c|c|c|c|c|c}
\hline & & I & 2 & 3 & 4 & 5 & 6 & 7 & 8 & 9 & I0 & I I & I2 & I 3 & I 5 \\
\hline Noise level-I & $\ldots$ & 43 & 3 I & 39 & 47 & 46 & I6 & I7 & 45 & 26 & 46 & I2 & 52 & 06 & I I \\
Noise level-2 & $\ldots$ & 47 & 59 & 55 & 44 & 53 & I3 & 43 & 57 & 46 & 45 & 34 & 5 I & 26 & 35 \\
\hline
\end{tabular}

The conclusion, then, is that confusion between noisy patterns is mainly a matter of loss of regularity in the pattern. If patterns become undetermined, wild, asymmetrical, and unstable, they tend to be confused with other patterns of this kind.

(3) They tend to be confused, that is, according to very global spatial characteristics. Are these confusion groups related to factor III? This factor was tentatively
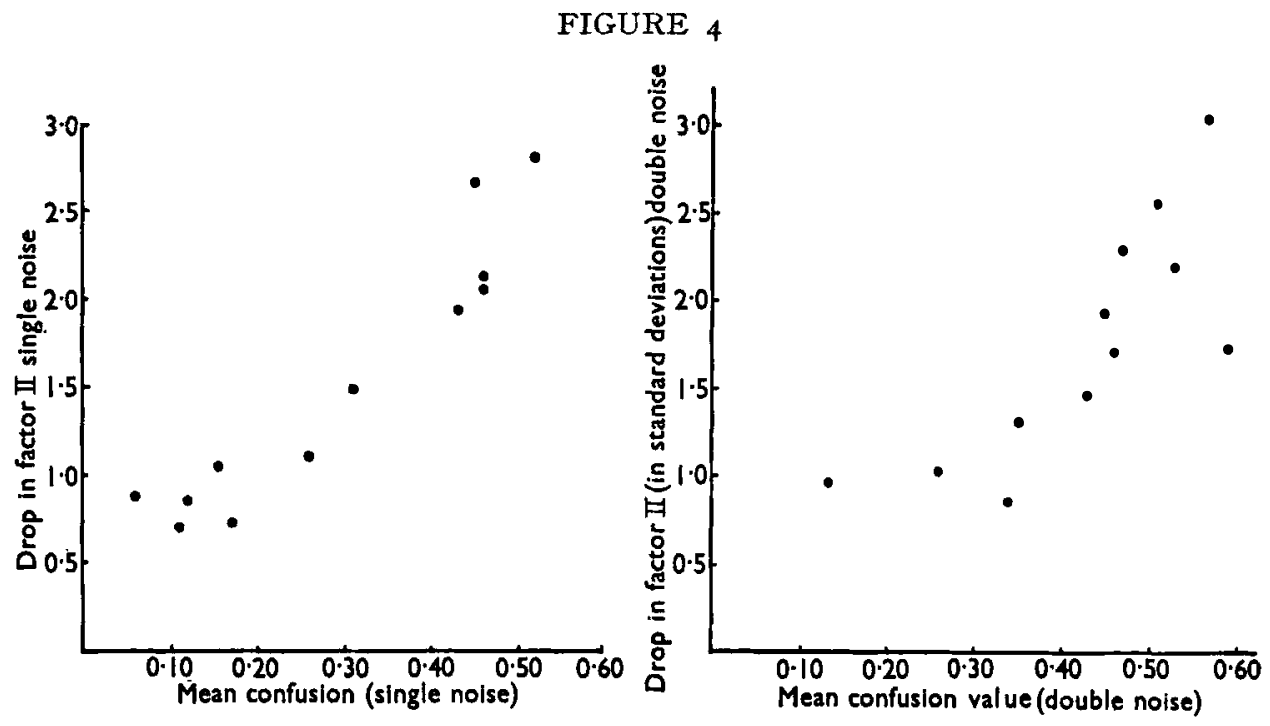

General confusability of a pattern (mean confusion values--Table VI) is highly related to drop in factor II if noise is added (Table III).

labelled gestalt or complexity factor-it did not only refer to form qualities but also to spread of the fixed position over the matrix. We see from Figure 5 that a relationship is indicated. The patterns at one extreme of factor III form one confusion group, those at the other end make up the two other groups. This difference is significant even for each noise level taken apart. Pattern 6 is a case by itself again.

\section{General conclusions}

The general conclusion from both experiments, is that human perceivers have a very high tendency to make type II errors, if they have to detect a visual pattern disturbed by noise. Even a moderate amount of noise (moderate in the sense that an ideal detector could easily and nearly faultlessly make correct decision) is detrimental to the perception of temporally presented patterns. The human organism has only a very limited capacity to separate stochastic components from the fixed canvas to 
which they are attached. A similar conclusion arises from the work by Corbin, et al. (1956, I958) on detection or convergent grouping in display of dots.

We found that confusion between patterns is mainly a matter of enhanced irregularity. Stable and even patterns are more noiseproof than irregular and undetermined patterns. Patterns which are most affected by noise in this respect tend to be the more easily confused. Patterns appear to fall into groups in that any pattern is mainly confused with alternatives belonging to the same group. These confusion groups appear to arise from very global criteria of spatial orientation.

Our experiments were exploratory. Further research should inform us about the precise nature of the perception of stochastically specified events. A primary question is whether the poor performance of the human perceiver is typical for temporally presented patterns, or whether this result also appears with patterns of simultaneous dots.

FIGURE 5

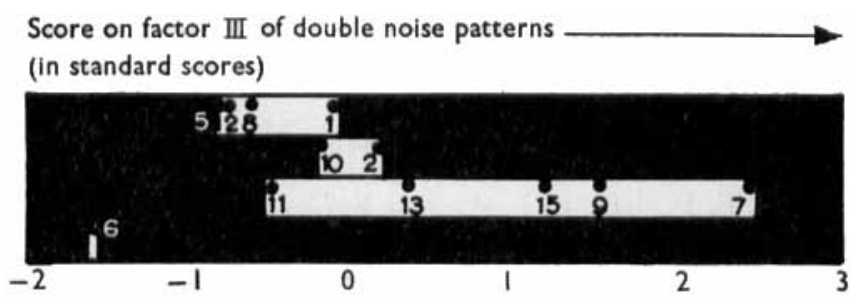

Score on factor III of single noise patterns

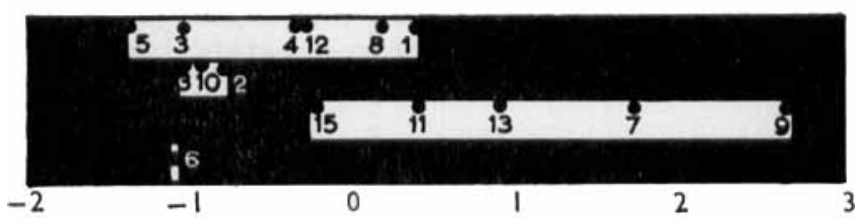

Score on factor III of double noise less patterns

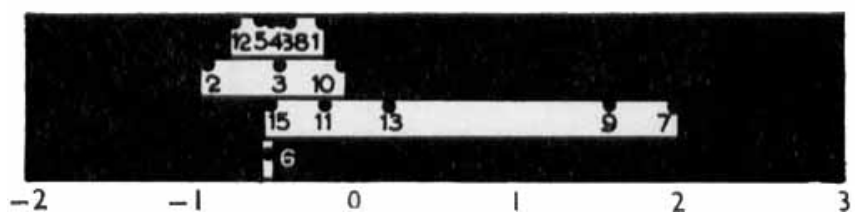

The patterns having high loadings on the gestalt factor form one confusion group, those with low ones make up the two other groups. This difference is significant for each of the three noise levels taken separately. Pattern 6 is a case by itself.

Further, many kinds of successive presentations are possible. Some patterns from our study (e.g. square, circle, star, helix) are completely specified by the location only of the dots of which they are composed. One might present these dots in any order of succession without changing the pattern. A particular order here is comparable to a manner of scanning of the pattern. In other patterns, however (like dance, glue, bouncer), the nature of the pattern arises from the specific order of the positions, every different order giving a new kind of pattern. In our study no attempt was made to control this kind of variation. 
While it is well known that the nature of the scanning process affects the spatial impression of a group of dots we do not know of any systematic research on this phenomenon. But there are some suggestive results from studies by Michotte and De Clerk (I95I) and by Christian and Von Weizsäcker (I943). Michotte showed that a radar-sweep-like presentation of spatial patterns is detrimental to pattern identification, any pattern tending to be perceived as a circle. The second study is alleged to show that the position of a circular pattern relative to the centre of the scanning rotation affects the nature of the visual perception of the pattern. The conclusion of this study was somewhat unsatisfactory; one feels in spite of the depth of the theory brought forward by Von Weizsäcker, that we might learn something more precise about this kind of effect. The nature of the perception reveals an unconscious mathematician in our mind, Von Weizsäcker says-our conclusion is that this mathematician is not very good at statistics.

\section{REFERENCES}

Attneave, F. (1954). Some informational aspects of visual perception. Psychol. Rev., 61, 183-93.

Christian, P., and Von Weizsäcker, V. (1943). Ueber das Sehen figurierter Bewegungen von Lichtpunkten. Z. Sinnesphysiol., 70, 30-5I.

Corbin, H. H., Reese, E. P., ReEse, T. W., and VolkmanN, J. (1956). Experiments on visual discrimination, 1952-55. Final Report, Mount Holyoke College, Mass., 39-50.

Corbin, H., Carter, J., ReEse, E. P., and Volkmann, J. (1958). Experiments on visual search, 1956-57. Final Report, Mount Holyoke College, Mass.

French, R. S. (I954). Pattern recognition in the presence of visual noise. J. exp. Psychol., 47, 27-31.

MICHOTTE, A., and DE CLERK, J. (I95I). Structures perceptives circulaires correspondant à des formes géométriques angulaires. Anné psychol., 50, 305-26.

RosenblatT, F. (I958). The perceptron. A theory of statistical separability in cognitive systems. Cornell Aero. Lab. Rep. VG-1 196. 